\title{
Geodiversity Research Methods in Geotourism
}

\author{
Magdalena Kuleta \\ Faculty of Earth Sciences, University of Szczecin, ul. Mickiewicza 18, 70-383 Szczecin, Poland; \\ kuletkaram1500@wp.pl; Tel.: +48-78-383-7760
}

Received: 16 April 2018; Accepted: 29 May 2018; Published: 31 May 2018

\begin{abstract}
With the emerging new approaches in the field of geodiversity, we can get better use of geographic space in geoparks and increase the number of geotourism destinations. Depending on what we want to study in geodiversity, a suitable research method should be adopted. No method is wrong, because various features of objects be examined this manner. In this study, the main objective is to identify and present not only quantitative but also qualitative character of geodiversity issue. Qualitative and quantitative features of objects based on appropriate categorization and their reference to scales, are to designate areas suitable for sustainable geotourism. It is important to develop a methodological approach in line with the chosen objective. The following material is a presentation of the most frequently used methods in the geodiversity of their purposes and use in geotourism.
\end{abstract}

Keywords: geodiversity; geotourism; methods in geodiversity; sustainable development

\section{Why Geodiversity Methods for Geotourism}

Geotourism, defined as "tourism that sustains or enhances the geographical character of a place, its environment, culture, aesthetics, heritage, and the well-being of its residents", is a concept that was introduced in a 2003 report by the Travel Industry Association of America and National Geographic and successively adopted by Hose [1]. The aim of geotourism is to prepare offers to attract as many visitors as possible. The concentration of tourism will depend on places of good accessibility, development and information on the area and natural elements of the so called geosites. For this geotourism needs the geodiversity because it should be considered also and above all in the spatial and temporal aspect. Geodiversity has been defined as "the natural range (diversity) of geological (rocks, minerals, fossils), geomorphological (landform, processes) and soil features. It includes their assemblages, relationships, properties, interpretations and systems" [2]. This means that complexity, diversity and spatial variability will determine the geotourism's attractiveness. Connectivity and sensitivity amongst landscape elements are highly varied over space and time, leading to divergence and increasing diversity over time. By using these principles within constrained chronologies of landscape change, studies of geodiversity can become a valuable tool in ecosystem management and the delivery of ecosystem services, including sustainable geotourism [3]. Currently there is a need to intensify works on geodiversity, in particular with reference to the following issue: establishing legal basis for geodiversity protection, e.g., geoparks and geosites [4]. Natural diversity includes biotic elements—-biodiversity—and, abiotic elements—geodiversity. According to Brilha, geological heritage, or geoheritage, refers to in situ occurrences of geodiversity elements with high scientific value-geosites-and ex situ geodiversity elements that, in spite of being displaced from their natural location of occurrence, maintain a high scientific value (for instance, minerals, fossils, and rocks available for research in museum collections) - geoheritage elements. In addition to scientific value, both in situ and ex situ geoheritage may also have educational, aesthetic, and cultural value, which also justify their necessary use by society (teaching/learning, tourism, leisure, etc.). 
Geoheritage is a general term that encompasses more specific designations when considering particular types of geodiversity elements with exceptional scientific value. Hence, it is common to refer to geomorphological (landforms), petrological (rocks), mineralogical (minerals), palaeontological (fossils), stratigraphic (sedimentary sequences), structural (folds, faults, and others), hydrogeological (water), or pedological (soils) heritage as sub-types of geoheritage. Considering that geoheritage is only justified by the scientific value, the relevance of geoheritage can only be international or national because there is no "local science" [5].

The application of geodiversity in geotourism can refer to the environmental, economic and social character (Figure 1). It should be noted that the destruction of geosites is irreversible, which is why some of them need special protection. For this reason, natural objects that have low susceptibility to degradation will have a special interest in geotourists. The geodiversity can be a new meaning and use of natural non-living objects as well as the protection of the abiotic environment. The geodiversity in economics may be manifested in the emergence of a new geotouristic infrastructure, including trails, museums, exhibitions of rare specimens, all kinds of markings and research stations. In addition, this means subsidies or financial revenues associated with the growing number of destinations. The social element of geodiversity is generating in new jobs and expanding the scientific and research staff. The scientific and didactic aspect may increase awareness among tourists. Due to various geotouristic needs, newer methods are used, which are selected depending on, for example, terrain, potential natural hazards or the preparation of a tourist offer. It should be noted that the methods are used in the right order, i.e., the implementation of the geodiversity map will not take place without prior detailed site inventory. As so, it is particularly important for geotourism to develop methods, tools and research techniques. The research method is usually considered as a clearly defined procedure, all assumptions and rules, or the choice of the type of action aimed at obtaining answers to the questions posed in a conscious, systematic and repeatable manner [6].

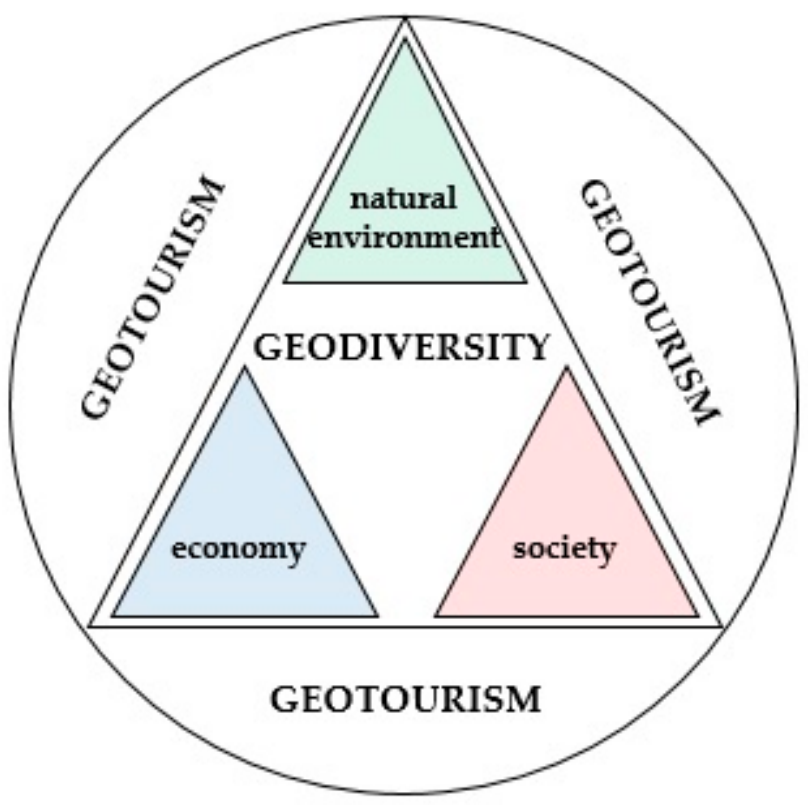

Figure 1. Sustainable development of geodiversity in geotourism.

Sustainable development was defined by the World Commission on Environment and Development in Our Common Future as "development, which meets the needs of the present generation without compromising the ability of future generations to meet their own needs". This definition implies that one of the main strategic objectives should be to stimulate economic activity within the framework of sustainable development [7]. In this case, the relationship between geotourism and geodiversity will be based on the principle of sustainable development. Geodiversity 
can be useful for planning a geotouristic offer with a simultaneous conservation plan for natural objects and can be used for promotional purposes.

\subsection{Research Objectives in Geodiversity}

It is important to recognize why geodiversity is evaluated. Depending on the needs of geoparks or other territories, various objectives are taken into account. The chart (Figure 2) was created by the review of over 100 articles and research papers which refer to the motives of geodiversity research. The choice of individual articles was conditioned by three main criteria. First of all, the articles published in the years 2015-2018 were taken into account in order to get the most up-to-date list, however some articles were selected from 2010-2015 and the reason is the other two criteria. Second of all, the direct content of the text referring to the quantitative and qualitative geodiversity. Nevertheless, not all authors use the characteristics of both categories, therefore the author took into account the articles only with a quantitative or only qualitative value. Third of all, is diversity, which in this case testifies the origin of articles from different countries (geotourism institutions, geoparks or universities). The largest number of articles was selected from sources such as: Geoheritage, Geotourism (Geoturystyka), GeoJournal of Tourism and Geosites and Geophysical Research Abstracts (EGU, Vienna, Austria, General Assembly. The author used scientific works, which include among others: Brilha, 2016 [5]; Farsani et al., 2014 [8]; Henriques and Brilha, 2017 [9]; Kapera and Różycki, 2015 [10]; Forte et al., 2012 [11]; Lima et al., 2014 [12]; Kot and Sobiech, 2013 [13]; Najwer and Zwoliński, 2014 [14]; Reynard et al., 2016 [15].

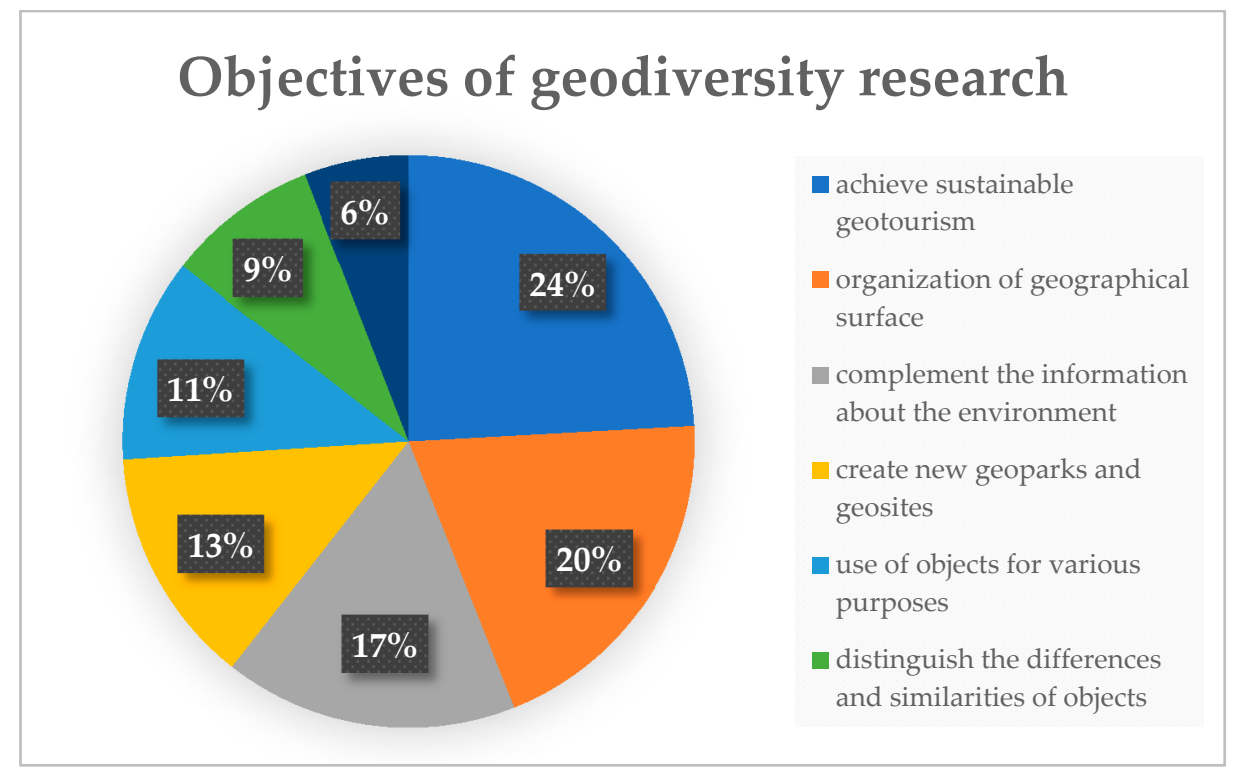

Figure 2. The most common scientific reasons for geodiversity research.

From all scientific reasons, the most common motive for research into geodiversity is to achieve sustainable development in geotourism. Each individual reason gives practical meaning in the application of geodiversity, nevertheless, its greatest use is reflected in geotourism. This is due to the uneven distribution of attractiveness in geopark areas and the increase of geotourism destinations without negative effects in the natural environment. In addition, the year 2017 was declared as the International Year of Sustainable Tourism for Development among others for geoparks. Therefore, it is important to understand and use geodiversity for the purposes of UNESCO and Global Geoparks organizations. In the author's opinion, the recognition of geodiversity in the light of the tasks of the above organizations has an impact on its popularity as well as on strengthening the importance in science and the development of newer methods for the emerging research problems (Figure 2). 


\subsection{The Most Decisive Features of Quantitative and Qualitative Geodiversity}

Geodiversity can be used for a variety of purposes. On the basis of many scientific publications, it is of utmost importance for geotourism in the context of the preparation of geotourism-attractive territories for potential tourists and thus for increasing the number of destinations and promoting the territory. But not only human is the cause of research on geodiversity. The second and more recognizable cause is geographic space and its rational use. It seems that at the current stage of the development of geodiversity research methods, qualitative-quantitative methods are the most advanced and best assess the geodiversity of the study area [16]. In particular, we mean for geoheritage a generic but descriptive term applied to sites or areas of geologic features with significant scientific, educational, cultural, or aesthetic value. In some zones of the Earth the natural abiotic environment is particular important and it is concentrated in a limited protected geographical area, the geoparks, where geological heritage sites are part of a holistic concept of protection, education and sustainable development [17]. Therefore, the natural objects of the so-called geosites are the basis for all used methods. It should be asked if geosites data will be taken into account as the entire examined area or perhaps as individual elements. According to its quantitative and qualitative characteristics, geosites are interpreted as a group of objects in a specific field-a polygon (quantitative geodiversity), or as an individual object-point (quantitative and qualitative geodiversity).

The quantification of geodiversity is an important step in all this process but still few researchers are investing in the development of a proper methodology. The assessment methodologies that were published so far are mainly focused on the evaluation of geomorphological elements, sometimes complemented with information about lithology, soils, hydrology, morphometric variables, climatic surfaces and geosites. This results in very dissimilar areas at very different spatial scales, showing the complexity of the task and the need of further research. This current work aims the development of an effective methodology for the assessment of the maximum elements of geodiversity possible (rocks, minerals, fossils, landforms, soils), based on GIS routines. The main determinant factor for the quantitative assessment is scale, but other factors are also very important, such as the existence of suitable spatial data with sufficient degree of detail. It is expected to attain the proper procedures in order to assess geodiversity at different scales and to produce maps with the spatial representation of the geodiversity index, which could be an inestimable contribute for land-use management [11]. Table 1 shows the most distinguished quantitative and qualitative features. It should be remembered that the quantitative classification of geodiversity may vary depending on the terrain that we are investigating, while the qualitative classification depends on the purpose in which we conduct the research.

Table 1. Most used features of quantitative and qualitative geodiversity.

\begin{tabular}{cc}
\hline Quantitative Geodiversity Features & Qualitative Geodiversity Features \\
\hline geomorphological & educational/scientific value \\
paleontological & value of availability \\
mineralogical & value of object condition and threat \\
petrological & semantic value \\
stratigraphic & special qualities * \\
tectonic & economical value \\
hydrological & connection with biodiversity \\
hydrothermal & function in environment \\
volcanic & natural hazard risk \\
speleological & \\
sedimentary & \\
marine & \\
glacial & \\
\hline
\end{tabular}

* Archaeological, cultural, ecological, historical, landscape. 
In order to thoroughly prepare the area for the analysis of geodiversity, the quantitative and qualitative characteristics of abiotic natural objects should be taken into account. Quantitative features are designed to change the number of objects present in a given area, while qualitative features are complementary. Quantitative is not only the number of objects themselves, but also the number of categories (features), for which the given object belongs. And this quantity should be used to further characterize geodiversity. Quantitative features are nothing else than geological and geographic categories that describe the endo and exogenous conditions that shape a given object. In turn, qualitative represent the object's application or its value. High geodiversity can implicates in geotourism development when occur as high qualitative as quantitative value.

\section{Most Commonly Used Methods in Geodiversity}

(1) Observation and monographic methods

Data methods are based primarily on information from scientific articles, magazines, maps or direct information from geoparks. They rely on the inventory of the natural environment together with the categorization of its individual elements. These methods:

- $\quad$ are used to recognize terrain and its initial characteristics,

- allow to recognize other previously unknown features of natural objects,

- report on the condition of the natural environment,

- allow you to sort out the information you have so far,

- the basis for the further complex calculations.

(2) Statistical methods

These methods are mostly the calculation of indexes, point ranking of objects, integration of abiotic features or landscape measures. Usually, they are the second step of geodiversity approach and they can:

- allow to distinguish the differences and similarities of objects,

- give to the objects a scientific character,

- use different values of objects for different purposes.

(3) Computer simulation methods

Mainly, they are used to illustrate the actions or already the results of research on geodiversity. These methods are of different kinds from the linear programming models, generated geodiversity maps, digital elevation models through the multicriteria analysis and analytic hierarchy process. These methods:

- allow for a better organization of geographical space,

- help in the promotion of sustainable development of geotourism.

\subsection{Geodiversity Methodological Approach}

It should be remembered that geodiversity is the description of geological and geographical elements, which means that they should be presented on the map. The author presents the proposals of methodological proceedings and the problems and possible solutions appearing at the same time.

\subsubsection{Inventory of the Natural Environment in Terms of Geodiversity}

Making an inventory of geodiversity it means to identify all geographic (spatial forms) and geological elements (litho-, geomorpho- and hydro-diversity), based on literature and observations. The most meticulous and pictorial way is to draw up inventory tables. The problem of the first step is that it is very difficult to make an inventory of all the features of the objects and to present them 
simultaneously on the one map. The solution can be to designate the objective for which inventory is made and based on it and reduce the characteristics of the objects. Therefore, the author believes that the so-called geodiversity map scheme, cannot be obtained. Each area differs, for example in terms of morphology, and features that are taken to methodological approach will depend on the occurrence of individual natural objects. Detailed material is the basis for further advanced research that is why it needs to be prepared with all occurring object and their descriptions. In the given stage the monographic and observation methods will be used. Kubalikova, 2013 [18] showed different criteria used for assessment extracted by different universities. Interesting inventory can be found in a publication from the Azores geopark by Lima et al., 2014 [12].

\subsubsection{Categorization of Geodiversity Characteristics (Quantitative and Qualitative)}

Subjective categorization and also lack of one categories scheme can occur because there are different objects in different areas. The solution can be categorization which refers to different scales (global, international, national, regional and local), and to all the features existing on the Earth (endogenous and exogenous). The author, in contrast to the statement on the scheme of one map of geodiversity, believes that it is possible to list all quantitative and qualitative objects that have been so far established. Cooperation with GGN (Global Geoparks Network) can be very helpful from all geoparks in the world. With all this data a map of geodiversity can be prepared.

\subsubsection{Implementation of Geography Map and Selection of Basic Field and Ground Position}

The geodiversity map has not been established as a scheme of conduct until now. A comprehensive map of geodiversity evaluation can be generated using the accepted rating scales. The difficulty to select a basic field may concern different shapes and sizes of fields. The solution can be to select the most common primary field as square. Methodological difficulties result from cutting natural borders with a grid of such fields, as well as with arbitrariness position changes in relation to the test area and size square. In the case of geological maps, you can apply natural lithological borders as basic fields and calculate their diversity for individual lithostratigraphic precipitates. This stage is clearly shown in the publication of Miśkiewicz, 2009 [19], Kot, 2012 [20], Zwoliński, 2012 [21].

\subsubsection{Assessment of Geodiversity}

Difficulties can be related to the subjective assessment of the incomparability of linear and point linear objects. The solution can be to create an index of total geodiversity. All geological features observed on the subject area and suitable for geotouristic should be added up. Each trait should have the same rank, which eliminates subjectivity assessment. The disadvantage of this assumption may be imported to the common denominator of different qualities. Additionally the typical exposure of rocks or stratotypes. Such features have a special didactic value. Problematic area seems to be valued due to different pitching slopes. Such parameter (inequality coefficient) however, can be created to enter the overall assessment of geodiversity. In a publication by Serrano and Ruiz-Flaño in 2009 [22], it can be found geodiversity index where quantitative elements are included:

$$
\mathrm{Gd}=\mathrm{Eg} \mathrm{R} / \ln S
$$

where:

- $\quad$ Eg-is a number of physical features defined for given unit area,

- $\mathrm{R}$-is a roughness coefficient of unit area,

- $\quad \mathrm{S}$-is the surface of unit area.

The most difficult to define is the $\mathrm{R}$ coefficient, which represents the morphological heterogeneity of the evaluated terrain. This index was used for example by: Órsi, 2010 [23], Kot and Sobiech, 2013 [13], Najwer and Zwoliński, 2014 [14]. 


\subsubsection{Visualization of Geodiversity Assessment}

There is no unified value scale but the solution can be to use the cartographic methods based on qualitative and quantitative characteristics analysis. The visualization of the results of analyzes is most often presented using histograms. The problem is to determine the rating scale: 3-step (low, medium, high geodiversity), 5-stage (very low, low, medium, high, very high geodiversity), 10-degree etc. It is difficult to determine on the basis of what criteria to adopt such a scale, which should definitely be unified in order to be able to compare different areas. In this step there are publications which use the basic units on the map (polygons, lines, points), or use the method of cartogram or cartodiagram. Interesting map of geodiversity visualization can be found in several publications: Zwoliński, 2012 [21], Reynard et al., 2016 [15], Silva et al., 2013 [24]. These authors presented gemorphosite assessment maps which are similar to the geodiversity ones. Reynard in contrast to other mentioned authors, presents geodiversity as quantitative entity, the other ones show geomorphosites as a particular examples of geodiversity which correspond with two approaches to geodiversity as mentioned in the first paragraph of this communication.

\subsubsection{Assignation of Geodiversity Regions}

There are some difficulties in determining what means the geodiversity region. It must be a closed boundary on the territory of which the given geodiversity value differs from the neighboring ones. Defining regions with high, medium and low value of geodiversity, according to the author, is not very correct. In author's opinion, in every part of the earth (regardless of latitude, climate, geological processes or terrain morphology), five regions of geodiversity can be distinguished. These regions are: I-region of high quantitative and qualitative geodiversity; II—region of high quantitative and low qualitative geodiversity; III-region of the average quantitative and qualitative geodiversity; IV—region of high qualitative and low quantitative geodiversity; V—region of low qualitative and quantitative geodiversity. No author distinguishes or defines regions separated on the basis of the assessment of geodiversity.

Apart from research methods, didactic methods are also distinguished in science. Geological content is transferred in schools in a selective manner and so far, geology has not been given a separate subject in primary education. Geotourism should develop didactic methods related to the interpretation of knowledge in the field of earth sciences. The most important challenge will be the proper development of information boards placed on tourist paths, as well as appropriate preparation of auxiliary materials such as guides, catalogs, maps, etc. Theoretical foundations for the construction of teaching paths and information panels and questionnaires for verification of theoretical assumptions should be included in the scientific basis of geotourism [25].

\section{Final Remarks}

A review of literature related to geodiversity, and in particular the methods of its evaluation, indicates that this issue is very modestly developed. While the methodological approach to geodiversity can be considered to be fairly well understood, the methods of geodiversity research leave much confusion. Regardless of the reasons for the analysis of geodiversity (Figure 2), and independently of what quantitative and qualitative elements have been used (Table 1), the methodological approach proposed by the author may be helpful in ordering the current attempts and approaches to measure geodiversity. It is important that the characteristic is done in the right order. One of the most important processes in understanding the measurement of geodiversity is detailing and refining each stage of the given procedure. A positive aspect is the interest and numerous attempts to visualize geodiversity. It must be realized that all scientific approaches can contribute to the development of a single geodiversity assessment scheme.

Each scientific discipline should have clearly defined research objectives. These objectives are mainly related to the analysis of geodiversity, the development of spatial planning for facilities 
and areas with geotouristic values, the development of geology interpretation methods for better understanding by nonprofessional customers, and the development of geotourism protection methods. The above course of analysis of geodiversity research methodology in geotourism leads to the conclusion that geotourism can be based on scientific principles, and thus can be the subject of scientific research, in particular applied sciences. This is one thing from many activities within the framework of geotourism, which is not only a research field, but also a multidisciplinary idea. It seems that at the current stage of the development of geodiversity research methods, qualitative-quantitative methods are the most advanced and best assess the geodiversity of the study area. Their particular advantage is the integration of data from different sources and with different substantive content. Such research will be important in spatial planning, which consists of among others determination of protected areas, geotouristic areas or geoparks. Standardization of procedures will support the development of these researches.

Conflicts of Interest: The author declares no conflict of interest.

\section{References}

1. Hose, T.A. 3G's for Modern Geotourism. Geoheritage 2012, 4, 7-24. [CrossRef]

2. Gray, M. Geodiversity: Valuing and Conserving Abiotic Nature, 2nd ed.; Wiley Blackwell: Chichester, UK, 2013.

3. Thomas, M.F. A geomorphological approach to geodiversity-Its applications to geoconservation and geotourism. Quaest. Geogr. 2012, 31, 81-89. [CrossRef]

4. Kozłowski, S. Geodiversity. The concept and scope of geodiversity. Prz. Geol. 2004, 52, 833-837.

5. Brilha, J. Inventory and quantitative assessment of geosites and geodiversity sites: A review. Geoheritage 2016, 8, 119-134. [CrossRef]

6. Hajduk, Z. Ogólna Metodologia Nauk; Redakcja Wydawnictw Katolickiego Uniwersytetu Lubelskiego: Lublin, Poland, 2012.

7. Lazzari, M. Geosites, cultural tourism and sustainability in the Gargano National Park (southern Italy): The case study of the La Salata (Vieste) geoarchaeological site. Rend. Online Soc. Geol. Ital. 2013, 28, 97-101.

8. Farsani, N.T.; Coelho, C.O.A.; Costa, C.M.M.; Amrikazemi, A. Geo-knowledge management and geoconservation via geoparks and geotourism. Geoheritage 2014, 6, 185-192. [CrossRef]

9. Henriques, M.H.; Brilha, J. UNESCO Global Geoparks: A strategy towards global understanding and sustainability. Episodes 2017, 40, 349-355. [CrossRef]

10. Kapera, I.; Różycki, P. Podstawy rozwoju geoturystyki na Wyspach Kanaryjskich ze szczególnym uwzględnieniem Lanzarote. Ekon. Probl. Tur. 2015, 29, 223-240.

11. Forte, J.; Brilha, J.; Pereira, D.; Nolasco, M. Quantitative evaluation of geodiversity: Development of methodological procedures with application to territorial management. In Proceedings of the EGU General Assembly 2012, Vienna, Austria, 22-27 April 2012.

12. Lima, E.A.; Nunes, C.J.; Costa, M.P.; Machado, M. Basis for the geological heritage management in the Azores Archipelago (Portugal). J. Integr. Coast. Zone Manag. 2014, 14, 301-319. [CrossRef]

13. Kot, R.; Sobiech, M. Ocena georóżnorodności rzeźby terenu wybranych fragmentów krajobrazu młodoglacjalnego Pojezierza Chełmińsko-Dobrzyńskiego. Rocznik Świętokrzyski. Ser. B Nauki Przyr. 2013, 34, 77-92.

14. Najwer, A.; Zwoliński, Z. Semantics and geodiversity assessment methods-Review and research proposal. Landf. Anal. 2014, 26, 115-127. [CrossRef]

15. Reynard, E.; Perret, A.; Bussard, J.; Granger, L.; Martin, S. Integrated approach for the Inventory and Management of geomorphological Heritage at the Regional Scale. Geoheritage 2016, 8, 43-60. [CrossRef]

16. Zwoliński, Z.; Najwer, A.; Giardino, M. Methods for assessing geodiversity. Geoheritage 2018, 19, $27-52$.

17. Lazzari, M.; Aloia, A. Geoparks, Geoheritage and Geotourism: Opportunities and Tools in Sustainable Development of the Territory. Spec. Issue Geoj. Tour. Geosites 2014, 13, 8-9.

18. Kubalíková, L. Geomorphosite assessment for geotourism purposes. Czech J. Tour. 2013, 2, 80-104. [CrossRef]

19. Miśkiewicz, K. Problemy badawcze georóżnorodności w geoturystyce. Geoturystyka 2009, 1-2, 3-12.

20. Kot, R. Zastosowanie indeksu georóżnorodności dla określenia zróżnicowania rzeźby terenu na przykładzie zlewni reprezentatywnej Strugi Toruńskiej, Pojezierze Chełmińskie. Probl. Ekol. Kraj. 2012, 33, 87-96. 
21. Zwoliński, Z. The routine of landform geodiversity map design for the Polish Carpathian Mts. Landf. Anal. 2012, 11, 77-85.

22. Serrano, E.; Ruiz-Flano, P. Geodiversity assessment in a rural landscape: Tiermes-Caracena area (Soria, Spain). Mem. Descr. Carta Geol. Ital. 2009, 87, 173-180.

23. Órsi, A. Quantifying the geodiversity of a study area in the great hungarian plain. J. Environ. Geogr. 2010, $1-4,19-22$.

24. Silva, J.P.; Pereira, D.I.; Aguiar, M.A.; Rodrigues, C. Geodiversity assessment of Xingu drainage basin. J. Maps 2013, 9, 254-262. [CrossRef]

25. Miśkiewicz, K.; Doktor, M.; Słomka, T. Naukowe podstawy geoturystyki-Zarys problematyki. Geoturystyka 2007, 4, 3-12.

(C) 2018 by the author. Licensee MDPI, Basel, Switzerland. This article is an open access article distributed under the terms and conditions of the Creative Commons Attribution (CC BY) license (http:// creativecommons.org/licenses/by/4.0/). 